\title{
Optimizing The Performance of Civil Servants: A Case Study at The Tax Counseling and Consulting Service Office (KP2KP)
}

\author{
Hardiyansyah \\ Sekolah Tinggi Ilmu Ekonomi Serelo Lahat \\ Email:dempo66@gmail.com \\ Aspi Zaitun \\ STIPSI Abdi Nusa \\ Email: aspizaitun22@gmail.com \\ Ade Firmansyah \\ KP2KP Indralaya, Ogan Ilir, Sumatera Selatan \\ Email: ade.firmansyah@gmail.com \\ Nidyawati \\ Sekolah Tinggi Ilmu Ekonomi Serelo Lahat \\ gumaynidyawati@gmail.com
}

\begin{abstract}
The performance of civil servants in the taxation sector will determine the success of state tax revenue. The purpose of this study was to determine and analyze the performance optimization of the KP2KP employees. Qualitative research with an explanatory research approach. Primary data sources were carried out through in-depth interviews with informants from the KP2KP, field observations, and the collection of written documentation. After analyzing the data, the researcher found that the optimization of the performance of civil servants with limited human resources can be realized through empowerment, development, competency improvement, employee motivation through adequate compensation, and leadership effectiveness in KP2KP. Research results are very important for policymakers in perfecting their policies. Optimizing the performance of civil servants through empowerment, development, increasing competence, providing employee motivation through adequate compensation, and leadership effectiveness in KP2KP. This study presents different points of view on the topic of civil servant performance. Increasing the performance optimization of civil servants with limited human resources is a new thing and according to the author's knowledge, the results of this study are the first to explain the increase in the performance optimization of KP2KP employees in Ogan Ilir Regency.
\end{abstract}

Keywords: Employee Performance, Service, Counseling, Taxation

\begin{abstract}
Abstrak
Kinerja PNS di bidang perpajakan sangat menentukan keberhasilan penerimaan pajak negara. Tujuan penelitian ini adalah untuk mengetahui dan menganalisis optimalisasi kinerja pegawai KP2KP. Penelitian kualitatif dengan pendekatan penelitian eksplanatori. Sumber data primer dilakukan melalui wawancara mendalam dengan informan dari KP2KP, observasi lapangan dan pengumpulan dokumentasi tertulis. Setelah menganalisis data, peneliti menemukan bahwa optimalisasi kinerja PNS dengan sumber daya manusia yang terbatas dapat diwujudkan melalui pemberdayaan, pengembangan, peningkatan kompetensi, motivasi pegawai melalui kompensasi yang memadai dan efektivitas kepemimpinan di KP2KP. Hasil penelitian sangat penting bagi pengambil kebijakan dalam menyempurnakan kebijakannya. Mengoptimalkan kinerja PNS melalui pemberdayaan, pengembangan, peningkatan kompetensi, pemberian motivasi pegawai melalui kompensasi yang memadai dan efektivitas kepemimpinan di KP2KP. Studi ini menyajikan sudut pandang yang berbeda tentang topik kinerja pegawai negeri. Peningkatan optimalisasi kinerja PNS dengan sumber daya manusia yang terbatas merupakan hal baru dan menurut pengetahuan penulis, hasil penelitian ini merupakan yang pertama menjelaskan peningkatan optimalisasi kinerja pegawai KP2KP di Kabupaten Ogan Ilir.
\end{abstract}

Kata Kunci : Kinerja Pegawai, Pelayanan, Penyuluhan, Perpajakan 


\section{Introduction}

Tax contribution to the posture of the Indonesian Budget (APBN) from year to year is increasingly dominant and significant. Based on the Budget Revision (APBN-2016), the tax revenue target was $\mathrm{Rp} 1,355.2$ trillion, or $75.9 \%$ of the state revenue target. It becomes the responsibility of the Directorate General of Taxes (DGT) of the Ministry of Finance of Indonesia Republic, thus demanding all vertical units of the DGT perform optimally. DGT has vertical units from the center to a local level. The bottom vertical unit of the DGT is the Office of Service, Counselling, and Taxation Consultation (KP2KP).

Following the Minister of Finance Regulation No. 206.2/PMK.01/2014 on the Organization and Administration of Vertical Institutions of the Directorate General of Taxes (RI, 2014a), KP2KP has the main duties and functions of conducting services, consultations, and counseling activities to the public, especially the taxpayers (TPs). In carrying out its duties and functions, KP2KP has several challenges that must be faced, such as limited human resources (HR), wide working areas, and a large number of TPs. Such conditions will have an impact on KP2KP performance.

KP2KP of Ogan Ilir regency is a vertical unit of DGT which is under the taxes service office (TS) of Pratama Kayu Agung and Regional Office of DGT South Sumatra and Bangka Belitung Islands. Human resources of KP2KP in Ogan Ilir Regency consisting of 3 civil servants (CS), 4 honorary workers, and 2 security personnel and has 23,893 registered taxpayers.

Having the limited human resource, wide working area, and the large number of TPs, it will have an impact on KP2KP performance. Such situations and conditions require solutions and concrete steps scientifically through conducting research on optimizing the performance of employees in carrying out duties and functions on KP2KP.

\section{Literature Review}

Researches on employee performance have been conducted by researchers in Indonesia, among others, by Salmiaty et al (2016); Haryadi et al (2016); Thahier et al (2016); \& Arfah et al (2016). The development of an advanced and modern organization in the era of globalization puts quality human resources as a valuable and important organizational asset that is often a competitive advantage for an organization with other organizations. The success of an organization to survive and develop is strongly influenced by the quality and quantity of human resources reflected in the performance of the organization. Dajani (2015) in his research results suggests that the employees involved can help their organization achieve its mission, execute its strategy, and produce important business results. Therefore, organizations today must actively hope to meet employee expectations and thus will create an impact on employee performance, which directly affects organizational performance.

KP2KP organizational performance engaged in the public service sector, regulated by the Minister of Finance Decree (MFD) Number 467/KMK.01/2014 on Performance Management in the Ministry of Finance (RI, 2014b). The MFD defines performance as the result of performing duties and functions of the organization and employees during a certain period.

Wirawan (2009) mentions that the performance of employees formed from several factors, namely internal environmental factors in an organization and external environmental factors in employee organizations. One of the internal factors of employees that affect performance is motivation. The influence of motivation on performance is reinforced by the results of Verbeeten's (2008) study which states that the incentive (external motivator) affects improving the performance quantitatively, but it does not affect the performance qualitatively. 
Several motivational theories can explain and describe the motivation of work owned by employees in an organization. Thoha (2014:221) mentions several motivational theories such as Maslow's hierarchy of needs theory that is a kind of hierarchy that regulates human needs starting from physical needs, safety, social (affiliation), rewards, and self-actualization. Next is Alderfer's theory of motivation (Alderfer's ERG theory) which classifies three needs affecting motivation, namely the need for existence, relationships, and the need to develop themselves.

Leaders or managers in an organization have a decisive role in motivating subordinates or employees. Managers who can create a workplace that ensures an appropriate goal for the satisfaction of the needs of subordinates and the suitability of individual goals with organizational goals will succeed in motivating subordinates. Also, a leader or a manager must be able to motivate employees by giving positive reinforcement such as appreciation, attention, and empowerment of employees.

Employee empowerment is one of the internal factors that affect the performance of the organization. Employee empowerment can be a means for managers or leaders to optimize employee performance. According to Cook and Macaulay in Widodo (2015:202), that empowerment is a change that occurs in the management philosophy that can help to create an environment where every individual can use their ability and energy to achieve organizational goals.

Implementation of empowerment of employees in an organization requires a strategy to realize it. According to Cook and Macaulay in Widodo (2015:206), several steps must be conducted for successful employee empowerment, that is a relationship with vision, directed by using examples, communicating effectively, strengthening teamwork, encouraging personal development, Customer services as the focus, and measuring the progress and recognizing and appreciating the success.

Motivation and empowerment of employees can act as an enabling factor to optimize the performance of employees with the condition there is a leadership following the needs of the organization. This is reinforced by Nugroho's (2006) research on the analysis of leadership factors and organizational culture as a factor affecting employee performance, with the results indicated that leadership factors had a positive and significant influence on employee performance.

Leadership is an activity to influence the behavior of others, or the art of influencing the behavior, or the art of affecting human behavior both individuals and groups (Thoha, 2014:262). Mintzberg in Thoha (2014:265-273) mentions three roles a manager or leader must-have for the organization he leads to be effective, namely the role of interpersonal relationships, role related to information, and role of decision-maker.

The theory of nature illustrates that the qualities of leadership are not entirely born, but can also be obtained through education and experience. Davids in Thoha (2014:287-288) formulated four common traits affecting leadership success in the organization; intelligence, maturity and social relationship, self-motivation and achievement support, and attitudes of human relation. Meanwhile, according to the House's path-goal theory in Thoha (2014:296-297) divides leadership styles into four styles: directive leadership, supportive leadership, participative leadership, and achievement-oriented leadership.

The solution to the limited human resource towards KP2KP's performance in carrying out its duties and functions is to optimize the performance of employees owned by KP2KP under the authority it possesses. Optimizing the performance of KP2KP employees can be achieved by 
applying high work motivation, empowering employees, and applying a leadership model and style following the needs of KP2KP organization.

\section{Research Method}

This research was conducted in KP2KP of Ogan Ilir Regency which was a vertical unit under the Tax Service Office (TS) of Pratama Kayu Agung with a working area covering Ogan Ilir Regency. The research used a qualitative method with an explanatory research approach that aimed to answer the root problems of a case through explanations. The data collection used observation techniques, interviews, and documentation. The in-depth observation was done by direct observation to retrieve data based on certain conditions for research such as observation of service activities and consultation to taxpayers at KP2KP Integrated Service Centre (ISC) of Ogan Ilir Regency. Interviewing 5 informants based on purposive sampling. The required documents related to the implementation of KP2KP duties and functions and the management of employee performance.

\section{Results and Discussion}

The vision and mission of KP2KP of Ogan Ilir Regency follow the vision and mission of the Directorate General of Taxes (DGT). DGT's vision is to be the best institution for collecting state revenues to ensure the sovereignty and independence of the state. To achieve this vision, the DGT has a mission of guaranteeing sovereign and independent state budgeting by:

a. Gathering acceptance based on high submission tax compliance and fair law enforcement;

b. Providing Modern technology-based services for easy fulfillment of tax obligations;

c. Recruiting Tax apparatus with integrity, competence, and professionalism; and

d. Competitive compensation based on the performance management system.

Duties and functions of KP2KP Ogan Ilir regulated in Article 63 and 64 of Regulation of the Minister of Finance (PMK) No. 206.2/PMK.01/2014 on the Organization and Administration Vertical Agency Directorate General of Taxation. Based on Article 63 of the Regulation of the Minister of Finance mentioned above, the Service Office, Counseling and Taxation Consultation have the following tasks: conduct service affairs; Counseling; Taxation consultations to the public; Observing the potential of regional taxation; Making tax monograph; Assist the Primary Tax Office in carrying out the service to the community. In carrying out the above tasks, KP2KP organizes several functions as stipulated in Article 64 namely: the implementation of services, counseling, socialization, and taxation consultation to the community; Observation of potential taxation and tax monograph making; Supervision of taxpayers' compliance obligations; The implementation and education of new Personal Taxpayer; Guidance and technical consultation of taxation to Taxpayers; Providing services to the public in the field of taxation to assist the Primary Tax Office; and the implementation of office administration.

The organizational structure of KP2KP consists of head office, administrative officer, and functional position group. The absence of functional groups causes limited human resources in KP2KP of Ogan Ilir Regency resulting impact on KP2KP performance of Ogan Ilir Regency in performing its duties and functions.

The main duty of KP2KP is related to the implementation of duties and functions of KP2KP Ogan Ilir regency including First; Service and Consultation. As an organization engaged in the public sector, KP2KP activities of Ogan Ilir Regency can not be separated from taxation service for Taxpayers. These taxation services and consultations are provided directly to the Taxpayers at the Integrated Service Center (ISC). Based on the Regulation of the Director-General of Tax No. PER-27/PJ/2016 on Service Standards in Integrated Service Areas of Tax Service Office (PDJP, 2016), ISC has four standards that must be met namely the standard of service management, 
human resources, facilities, and supervisions. Following the standard of service management, ICS of KP2KP Ogan Ilir Regency is divided into three parts namely ISC Counters, help desk, and selfservice. Taxation service activities at ISC Counters include registration of Taxpayer Identification Number (TIN/NPWP), receipt of Period and Annual Tax Return (SPT). Taxation consultation activities at the ISC help desk include EFIN consultation, e-Billing, e-Filing, e-Invoice, and other consultations. Based on the performance achievement of employees (CKP) which contains performance contracts, employee work goals (SKP), and service and consultation targets in 2016, service and consultation activities in KP2KP Kabupaten Ogan Ilir have achieved the set targets. The result of observation of service and consultation activities at TP2KP of Ogan Ilir Regency found two things as follows: (a) Empowerment of support staff in-service activity and consultation at Integrated Service Center (ISC) and help desk; (B) Contract of service performance and consultation in output is achieved, but the outcome still needs to be improved by increasing employee competency.

Second; taxation counseling by KP2KP shall be guided by the Regulation of the Director-General of Taxes Number PER-03/PJ/2013 concerning Taxation Counseling Guidance (PDJP, 2013). Under the regulation, counseling is an effort and process of providing tax information to the public, business, and government and non-government agencies. Counseling aims to improve knowledge and taxation skills and to change the behavior of the TPs to be more comprehensive, aware, and careful in carrying out the rights and meet the obligations of taxation. Taxation counseling is conducted based on taxation counseling management including planning, organizing, implementing and monitoring, evaluating, and reporting. The target of counseling is the Taxpayer Candidate, New Tax Payer, and registered Taxpayer. Based on CKP that contains Performance Contracts, SKP, and counseling targets in 2016, service activities in KP2KP Ogan Ilir Regency have exceeded the set target.

The observation results from taxation counseling activities in KP2KP Ogan Ilir, found two things they were: (a) The importance of leadership role from the head of KP2KP towards the performance of taxation counseling in the limited number of KP2KP counseling Team; and (b) The counseling performance contracts productively exceeded the set targets, but the outcome still needs to be improved by improving Team's counseling competence.

The interview results from informants could be classified by topic of question as follows: First; Quantity, Quality, and Employee Empowerment. Related to the quantity and quality of employees, all informants stated that the quantity of ISC and KP2KP Team of Ogan Ilir Counseling Officers was still lack of quality (competence) and unequal personals. It was supported by the statement of all informants that all employees had never attended the Training and In House Training (IHT) for improving competence and performance in services, consulting, and counseling. Related to the empowerment of supporting staff ISC Counters and help desks, all informants stated that because the condition of CS was limited and a large number of TPs should be served, the involvement of support officers could not be avoided even though it was not according to the rules / SOP/contract.

Second; Performance. Related to the effect of service performance and consultation on the information and answers needed by the TPs, four informants stated good and one informant stated still less because the help desk officer had not fully possessed the taxation regulations. As for the effectiveness of counseling on TP's knowledge and compliance, all informants answered effectively although according to one informant there was still a group of TPs who had followed the counseling but still needed guidance in the calculation, payment, and tax reporting. For factors affecting performance, all informants stated that leader factor, income, and training / IHT affected their performance. 
Third; Work motivation. Regarding providing additional income to the Support Officers, all informants stated that they could improve their work motivation. While the influence of duties and functions of KP2KP that must be implemented and the limited human resources possessed of their work motivation, all informants stated positively influence because they were challenged and motivated to improve performance, knowledge about taxation, and time management.

Fourth; Leadership. Related to the leadership role and head of KP2KP, all informants stated that the leadership of KP2KP played an important role in their performance and KP2KP performance, motivated work, became role model of employees, and built communication with external parties such as Local Government. Also, the informant stated that a Head of KP2KP had a role in regulating the implementation of KP2KP duties and functions, decision-making, planners and budget managers, and guiding, directing, and managing employees.

Under Human resource (HR) standards in ISC, ISC employees are divided into Core Officers and Support Officers. The Core Officer is the CS / CS Candidate at DGT who performs the duties and functions of the service in the ISC area. While the Support Officer is the officer who supports the implementation of the duties of the Core Officer. Honorary workers and security personnel are included in the category of Supporting Officers. The observations results indicated that the Support Officers were directly involved in the service activities at the ISC counter and consultation at the help desk counter. The involvement of honorary workers and security personnel in the service and consultation activities in TP2 KPP of Ogan Ilir Regency was also confirmed by an interview with informants. The interview results showed that all informants answered that because the condition of CS owned by KP2KP was limited and large number of Taxpayers that must be served, the involvement of Honorary workers and security personnel in the service and consultation activities in ISC can not be avoided even though it was not according to the rules / SOP/contract. Then on the condition of CS duty in ISC all informants replied that CS in Integrated Service was still less.

The involvement of honorary workers and security personnel in helping activities outside the main task from the point of view of Science Management can be called empowerment. According to Cook and Macaulay in Widodo (2015:202), empowerment is a change that occurs in the management philosophy that can help create an atmosphere where every individual can use his ability and energy to achieve organizational goals. Meanwhile, according to Clutterbuck in Widodo (2015:200), empowerment is an effort to encourage and enable individuals to assume personal responsibility for their efforts to improve the way they perform their jobs and contribute to the achievement of organizational goals.

Employee empowerment is carried out by a leader or manager by providing adequate responsibilities and authority for employees, education, and training to increase employee competence, create work synergies, make the best services, provide feedback on performance, and give trust to employees. Empowering employees within an organization will create an organizational atmosphere that leads to employees who have the initiative, innovation, and creativity in doing something necessary, even far beyond the usual job duties conducted to achieve organizational goals.

Implementation of employee empowerment within an organization including the empowerment of honorary workers and security personnel in KP2KP Ogan Ilir needs a strategy to optimize it. According to Cook and Macaulay in Widodo (2015:206), several steps must be taken to empower employees successfully, namely: (a) Relationships with vision. Connect empowerment with vision and mission and organizational value so that empowerment becomes part of organizational value. Honorary workers and security personnel should know and understand well the vision and 
mission of the DGT; (B) Directed by using examples. Empowerment should be considered that empowerment comes from top management, where leaders can provide the vision for the future and provide support and encouragement to create an atmosphere in which people are responsible for their destiny. Because Honorary workers and security personnel assist in administering activities outside the main task, the role of Head KP2KP is very important in guiding and directing it with examples. Based on the interview results from informants who mentioned that the Head Office's role was to guide, direct, and manage employees. Besides, according to leadership theory of House version (1996) is so-called directive leadership; (C) Effective Communication. Engaging employees in communication and inconsistent feedback discussions, so organizations can encourage empowerment. In guiding and directing honorary workers and security personnel, a Head Office of KP2KP should be able to communicate effectively. This condition is in line with the theory of Mintzberg (1973) that a leader has an informational role; (D) Strengthen teamwork. The empowerment of honorary workers and security personnel in service and consultation activities at TP2KPP of Ogan Ilir Regency requires solid and cohesive teamwork with ISC Counter Core Officer and Help Desk. Solid and cohesive teamwork requires a leader who can play the interpersonal roles as mentioned by Mintzberg (1973); (E) Encourage personal development. Empowered employees need self-development to have good competence. Increasing employee competence can be conducted by holding training such as in-house training (IHT). This condition is confirmed by informant interview; (F) Make customer service as the focus. The result of empowerment is in improving service to the Taxpayers so that employees who are in ISC should be encouraged to be responsible to provide satisfactory service to Taxpayer; (g) Measure the progress that occurs and recognize and appreciate success. Service and consulting activities in ISC have measurable performance reflected in the performance contract and $100 \%$ performance achievement. The achievement should also be accompanied by an award to the Supporting Officer who has assisted in the service and consults the activities in ISC. This additional income was proven to improve their work motivation and based on interviews with informants; all informants stated that the additional income had a positive effect on their work motivation. This is in line with Maslow's hierarchy of motivation theory that a person has physical needs such as salary, benefits, homes, etc; (h) Contract of service performance and consultation in output is achieved, but the outcome must still be increased by increasing the competence of employees. Measuring the performance of an activity can be seen from the resulting output and perceived benefits. The target of service and consultation outcomes stated in the KP2KP performance contract of Ogan Ilir Regency has been achieved, but in terms of outcome still needs to be improved.

One of the expected outcomes of service and consultation activities is that New Taxpayers can know and understand well their taxation rights and obligations to become obedient Taxpayers. However, the condition that occurs is the level of compliance of new Taxpayers is still low so it should be improved. This condition can occur due to lack of information and explanation received by new TPs at registration of Taxpayer Identity Number (TIN) and limited competence of ISC Officer. Confirmed by the interview with informants. Based on these conditions, it is necessary to improve the competence of ISC Officers related to knowledge of taxation and communication skills through (a) Education and Training. Education and training can only be followed by civil servant/apparatus and is a top-down appointment from the Head Office of Directorate General of Taxes, and (b) In House Training (IHT). In-house, training can be defined as training that is implemented internally within an organization. Thereby increasing the competence of ISC Officers most possible by holding their own in house training as needed. This is also confirmed by the interviews from informants, where all informants stated that it was very necessary to be held in house training (IHT). 
Based on the guidance on counseling services, all CS/apparatus of KP2KP is a Counselling Team. KP2KP Ogan Ilir has only three people as Counselling Team who also as ISC Core Officer. Confirmed by the interview with informants, where all informants stated that the KP2KP Counselling Team of Ogan Ilir Regency was still less and unequal competent.

The condition of the Counselling Team, making the leadership role of a Head of KP2KP very important and determine the Counselling performance. The role of leadership of a Head of KP2KP in the Counselling activities confirmed by the results of informant interviews as follows:

a. Four informants stated that leadership factors play a role in improving KP2KP performance. In line with the theory of leadership path-goal theory House (1996) is a leadership style oriented to achievement. Also, Davis (1971) theory that the success of organizational leadership is influenced by the ability of self-motivation and achievement motivation.

b. Three informants stated that the leadership of KP2KP Head could motivate the work. The role of leadership of KP2KP Head that was able to provide work motivation in line with the theory of leadership of path-goal theory House version (1996) is a supportive leadership style (Supportive Leadership). With this style of leadership, a leader will be friendly, approachable, and have pure humane attention to his subordinates. Supported by Alderfer's (Alderfer's ERG theory) motivation theory of relatedness needs is a need to establish relationships with others, social relations, and cooperation with others. Without any cooperation and solid teamwork, the KP2KP Counselling target of Ogan Ilir Regency is difficult to achieve.

c. Three informants stated that the leadership of KP2KP Head could be a role model. The leadership role of the Head of KP2KP makes a leader become a role model following Mintzberg (1973) that a leader has an interpersonal role as a figurehead. As a figurehead, a leader will be a subordinate role model and a symbol to represent the organization he leads at every opportunity. The working area of KP2KP covers approximately one regency but there are also those covering more than 3 regencies. So it demands the role of Head of KP2KP as a figurehead to represent the organization in interacting with the Regional Governments.

d. One of the informants stated that the role of the leadership of Head of KP2KP is establishing communication with external parties such as Local Government.

The role of the leadership of KP2KP Head in establishing communication with external parties such as Local Government, based on Mintzberg (1973) that a leader has an informational role as Spokesman and the role of the solicitor as a negotiator. As a spokesperson, a leader has a role to convey information out of his or her organizational atmosphere. As a negotiator, a leader has a role in the area of negotiation with parties outside his organization and then takes a decision based on the agreement in negotiations. The implementation of Counselling activities requires cooperation with external parties. The Counselling activities of KP2KP of Ogan Ilir Regency targeted the treasurer of the Regional Work Unit (RWU) of Ogan Ilir Regency from Regent, Provincial Secretary, and Departments until village apparatus. Under these conditions, the role of $\mathrm{KP} 2 \mathrm{KP}$ Head as a spokesperson and negotiator is very important to be able to convince external parties to cooperate in taxation Counselling activities. Based on informant interview results, in line with previous research, Nugroho (2006) stated that leadership had a dominant influence on employee performance.

Counseling output performance contracts exceeded the targets set, but the outcome still needs to be improved through the improvement of the Counselling Team's competencies. Measurement of Counselling performance can be seen from the output and perceived benefits. In terms of output, the KP2KP Counselling performance of Ogan Ilir Regency has exceeded the set target. Meanwhile, terms of outcome effectiveness still need to be improved especially related to improving knowledge and compliance of taxpayers who are embedded as a Taxpayer Treasurer. 
Confirmed from the with informants, one informant stated there was still a group of taxpayers who had followed the counseling but still needed to be guided in the calculation, payment, and tax reporting. Improving outcome of taxation Counselling activities mainly related to the increase of taxpayers' knowledge and compliance can be done in several ways: (a) administering pre-test before delivering Counselling materials with the intent to measure the knowledge of the Taxpayer before following the counseling; (B) administering post-test after delivery of Counselling materials to measure the knowledge of the Taxpayer following after the counseling; and (c) Distributing questionnaires to participants to obtain input from participants regarding the implementation of taxation Counselling activities.

To administer pre-test, post-test and questionnaire require a good competent Counselling team. The interviews results with informants showed the opposite condition that all informants stated that the Counselling Team's lack of competence and all the Counselling team had never followed the personal potential and Counselling competency.

Considering the above conditions, capacity building, and competence of the Counselling Team related to taxation knowledge and communication skills are very important and urgent. It can be improved through education dan training or in-house training. Under the authority possessed by KP2KP, the most enabling capacity and competency of the Counselling Team is through IHT related to (a) Empowerment with good Competence; (B) Work motivation with appropriate compensation; (C) effective Leadership of Heads of KP2KP, and (d) Optimization of Employee Performance in KP2KP Ogan Ilir regency.

\section{Conclusion}

Based on the background of the research results and discussion, the conclusion that can be put forward in this study is that the optimization of employee performance at KP2KP Ogan Ilir Regency can be achieved through development, increasing competence, work motivation, and employee compensation, as well as increasing leadership effectiveness. To achieve this, it is recommended to (a) increase the capacity and competence of ISC Officers and the Counseling Team through IHT and/or education and training consistently and continuously; (b) providing appropriate compensation to Supporting Officers and additional ISC Core Officers and the Counseling Team to encourage the motivation of KP2KP employees to remain high; and (c) Leadership effectiveness of the head of KP2KP through transparent, fair and accountable selection by upholding integrity, professionalism, and competence.

\section{References}

Arfah, H., Basri, M., and Kahar, F. (2016). Employee Performance at Naval Command Headquarter in South Sulawesi, Indonesia. The Social Sciences, 11: 3788-3792. https://medwelljournals.com/abstract/?doi=sscience.2016.3788.3792

Davis, K. (1977). Organizational behavior: A book of readings. McGraw-Hill Companies.

Dajani, Maha Ahmed Zaki, (2016) "The Impact of Employee Engagement on Job Performance and Organizational Commitment in the Egyptian Banking Sector." Journal of Business and Management Sciences, 3 (5): 138-147. doi: 10.12691/jbms-3-5-1

Haryadi, Fika Rahmanita, Sutarmin and Dadang Prasetyo Jatmiko, (2016). The Impact of Design Components and Job Satisfaction on Employee Performance. International Business Management, 10: 4907-4916.

House, Robert J. (1996). "Path-goal theory of leadership: Lessons, legacy, and a reformulated theory". Leadership Quarterly. 7 (3): 323-352. https://doi.org/10.1016/S10489843(96)90024-7

Mintzberg, H. (1973). The Nature of Managerial Work, New York, Harper \& Row, Publishers. 
Nugroho, R. (2016). Analisis Faktor-Faktor Yang Mempengaruhi Kinerja Karyawan (Studi Empiris pada PT. Bank Tabungan Negara (Persero) Cabang Bandung). Tesis Program Magister Manajemen Pasca Sarjana Universitas Diponegoro. Semarang. Diponegoro University | Institutional Repository (UNDIP-IR)

Peraturan Direktur Jenderal Pajak Nomor ER-27/PJ/2016 tentang Standar Pelayanan di Tempat Pelayanan Terpadu Kantor Pelayanan Pajak. Jakarta, 2016.

Peraturan Direktur Jenderal Pajak Nomor PER-03/PJ/2013 tentang Pedomanan Penyuluhan Perpajakan. Jakarta, 2013.

Republik Indonesia. (2014). Peraturan Menteri Keuangan (PMK) Nomor 206.2/PMK.01/2014, Tahun 2014 tentang Organisasi dan Tata Kerja Instansi Vertikal Direktorat Jenderal Pajak. Sekretariat Jenderal: Jakarta.

Republik Indonesia. (2014). Keputusan Menteri Keuangan (KMK) Nomor 467/KMK.01/2014 tentang Pengelolaan Kinerja di Lingkungan Kementerian Keuangan. Jakarta.

Republik Indonesia. (2016). Undang-Undang Nomor 12, Tahun 2016 tentang Perubahan Atas Undang-Undang Nomor 14 Tahun 2015 Tentang Anggaran Pendapatan dan Belanja Negara Tahun Anggaran 2016. Sekretariat Negara: Jakarta, 2016.

Robert J. House \& Terence R. Mitchel. (1974). "Path-Goal Theory of Leadership" Journal of Contemporay Bussiness, Autumn, pp 81-97. https://doi.org/10.1016/S1048-9843(96)90024-7

Salmiaty, Tati. (2016). Improvement on Employee Performance. International Business Management, 10: 1708-1712.

Sugiyono. (2010). Metode Penelitian Kuantitatif Kualitatif \& RND. Alfabeta. Bandung.

Thahier, Rohana and Muhammad Faisal Risani, (2016). Leadership and Employee Performance in West Sulawesi Provincial Government-Indonesia. The Social Sciences, 11: 14771483. https://medwelljournals.com/abstract/?doi=sscience.2016.1477.1483

Thoha, Miftah. (1983). Perilaku Organisasi; Konsep Dasar dan Aplikasinya. Rajawali Pers: Depok.

Verbeeten, Frank H.M. (2008). Performance management Practices in Public Sector organizations: Impact on Performance. Accounting, Auditing \& Accountability Journal, 3: 427-454. https://doi.org/10.1108/09513570810863996

Widodo, Suparno Eko. (2015). Manajemen Pengembangan Sumber Daya Manusia. Pustaka Pelajar: Yogyakarta.

Wirawan. (2009). Teori, Aplikasi, dan Penelitian: Evaluasi Kinerja Sumber Daya Manusia. Salemba Empat: Jakarta.

\section{Copyright Disclaimer}

Copyright for this article is retained by the author(s), with first publication rights granted to the journal. 